\title{
Leader-Follower Expectations: Pygmalion in Management
}

\author{
Amber Raza ${ }^{1}$
}

\begin{abstract}
Leadership is a concept which has been explored, researched; and various theories have been developed on this concept. These theories have helped in achieving overall organizational efficiency. Pygmalion leadership style (PLS) is as yet a relatively unexplored area. This style includes behaviours that assist the subordinates to be productive in an organization. Leader behaviour and its impact on followers performance has been studied by various theorists abroad. Most of the researches have been conducted in military and educational settings. This study explores the impact of Leader's behaviour based on PLS and its impact on performance of the subordinate. Self-fulfilling prophecy is at the root of Pygmalion Leadership style hence two variables namely employee self-expectations and leader expectations have also been considered in the study. The study also aims to uncover the subordinates characteristics and expectations from a leader. A questionnaire was developed on a seven point Likert scale. Based on the secondary data, four variables were identified: expectation raising on selfexpectation, expectations from leader, leadership behaviour and performance of the subordinate. An analysis of 230 banking professionals was conducted. The data was analyzed using descriptive as well as correlation analysis which revealed that there is a link between performance and expectations. The correlation matrix revealed a significant relationship between performance of the subordinate and self expectation(0.98), performance of the subordinate and expectations from leader (0.75) and leader behaviour and performance of the subordinate(0.55).
\end{abstract}

Keywords: Pygmalion effect, leadership, self-fulfilling prophecy, expectations, performance

\section{Introduction}

\subsection{Background of the Study}

Leadership impacts upon relationships within the organization and the productivity of the organization. This correlation between leadership style and the performance and productivity of the employee has been studied by various researchers such as Kouzes and Posner (1995), Bass (2008), Kotter (1996), and Howell and Costley (2001). These research studies focused primarily on the leader's characteristics and not what the subordinate expected from a leader. Shamir, Pillai, Bligh, and Uhl-Bien (2007) are among few researchers who inquired the role of subordinates in an effective leadership style.

Most research studies still consider the role and productivity of a subordinate as a "by product" of a particular leadership style. Self-fulfilling prophecy was used by McGregor's (1960) theory $\mathrm{X}$ and theory $\mathrm{Y}$ as an explanatory variable on the level of motivation in subordinates. The theory points out that the level of assumptions (expectations) set by the manager yields the same kind of outcomes. The way the manager treats the subordinates, the subordinates react in the same way. As the theory outlines that the a manager using theory $\mathrm{X}$ as the benchmark mistrusts the subordinate; whereby not delegating tasks and observing too closely; this in return makes the worker put less effort in the job hence fulfilling the managers prophecy

${ }^{1}$ Amber Raza is Lecturer, College of Business Management, Institute of Business Management, Karachi, zaidi.razaa@hotmail.com

\begin{tabular}{llll|l}
\hline JISR-MSSE & Volume 11 & Number 2 & July - December 2013 & 29
\end{tabular}


explaining that the follower does not work. On the other hand, if the belief was set in on theory $\mathrm{Y}$ which highlights that the manager trusts his subordinates and delegates more creates an environment whereby the subordinate is given responsibility and this trust factor makes an individual respond by being more responsible and living up to the expectations. Hence McGregor used the concept of manager expectations as a key factor of productivity and selffulfilling prophecy. Similarly, Likert $(1961 ; 1967)$ was also aware of the concept of expectations and its implications on the effectiveness of the leader-subordinate exchange. He wrote of a highly effective manager: "His confidence in his subordinates leads him to have high expectations as to their level of performance and with confidence that he will not be disappointed; he expects much not little" (Likert, 1961).

Likert was the first theorist to have made a mention of expectation and leader-member exchange. However, Livingston (1969) eloquently and constructively discussed the role of expectations on followers' behaviour hence Pygmalion theory made an official entry through his article "Pygmalion in Management" published in Harvard Business Review. Although more than three decades have passed as far as the concept of Pygmalion has made an entrance in management, there is a dearth of research in Pakistan.

The main objective of the study is to explore the leader-follower expectations in banks, in order to validate the theory of Pygmalion in the local scenario.

\subsection{Significance of the Study}

The study is based on rather a less-explored area of research in management. Hence the study may help bank managers focus on skills, which are required to create an environment whereby the subordinates would work diligently and up to the expectations of the supervisor.

\section{Literature Review}

Leadership and its role in organizational performance has been explored by various management theorists and researchers. Yukl (2013) defines leadership as the process of "influencing others to understand and agree about what needs to be done and how to do it and the process of facilitating individual and collective efforts to accomplish shared objectives."

The styles of leadership include charismatic leadership, transformational leadership, Pygmalion and Goal setting; all the styles focus on different sets of variables. These variables form an interrelated and complex set of relationships and are so intertwined that it is difficult to identify which variable is more important in shaping an effective leadership style (Yukl, 2013). The various constructs developed over the last decade include the roles of goals, leader expectations and self-efficacy among supervisors and subordinates which help in improving organizational performance (Meier \& O’Toole, 2011).

There exists a plethora of research work on leadership; however, certain aspects such as the role of leaders' expectations and the subordinates' expectation from the supervisor are not explored in research studies. This study focuses on the leaders' behaviour (Pygmalion leadership style) and direct influence on the performance of subordinate, subordinates' selfefficacy and the expectations of the leader about subordinates' performance. 
Organizational goals and leader expectations are related but not identical factors in leadership theory. While organizational goals may be specific and operational, they often are general, abstract, vague or symbolic. Leader expectations may be more concrete. They can be perceived as organizational goals in action as they indicate what the leader regards as important for the organization to accomplish. High-level of leader expectations or challenging goals and their effects on organizational performance form key elements of several leadership theories, including the charismatic leadership, transformational leadership, Pygmalion leadership style and goal setting.

Theory of charismatic leadership advocates leadership as having appealing vision with optimism and confidence and make emotional appeals to values. Followers tend to personally identify with the leader and imitate his behaviour (Conger \& Kanungo 1987; Shamir et al., 1993). Transformational leadership theory shares some elements with charismatic leadership theory, including the leader's role in forming a vision, motivating subordinates and setting high expectations. The theory suggests that leaders can increase organizational performance by influencing employees' values and aspirations, inducing a purpose transcending short term goals, activating higher order needs and motivating employees to move beyond their own self interests (Avolio \& Yammarino, 2002; Judge \& Piccolo, 2004; Yukl, 2013).

\subsection{Performance of the Subordinate}

Pygmalion leadership style was initially studied in educational setting; however, Livingston (1969) created a hypothesis that Pygmalion can be studied in the management setting. He wrote that the manager's expectations of his subordinates directly impact upon the performance of the subordinates. Managers create high performance environments which yield high performance in subordinates. Self-belief of managers is also important to be successful to lead subordinates and help achieve high performance.

"The high expectations of superior managers are based primarily on what they think about themselves and about their ability to select, train, and motivate their subordinates. What the manager believes about himself subtly influences what he believes about his subordinates, what he expects of them and how he treats them. If he has confidence in his ability to develop and stimulate them to high levels of performance, he will expect much of them and will treat them with confidence that his expectations will be met. But if he has doubts about his ability to stimulate them, he will expect less of them and will treat them with less confidence" (Livingston, 1969).

This was the first time that a theorist had developed concrete evidence that there indeed is a relation between expectations and results. He further discussed the negative impact of low expectations. Self-esteem was also studied as the mediating relationship between expectations and performance.

\subsection{Self-expectation}

Self-expectation or self-efficacy is the individual's belief that he is capable of holding a particular position and hence is also able to accomplish tasks (Bandura, 1977). Similarly, the person's belief or expectations that accomplishing certain tasks properly is based on self belief (Hackett \& Betz, 1981). The type of behaviour to be displayed and the expected work 
with determination is all linked with self/fulfilling prophecies which were discussed in detail with linkages to outcomes (Bandura, 1977). Self-fulfiling prophecy or Self-efficacy when viewed through the same lense for careers it is evident that the same concepts can be applied to educational as well as organizational setting which in return would help achieve organizational and educational goals (Betz \& Hackett, 1997, p. 383). These behaviours are directly related with an individual's self/perceptions and the belief that they can achieve the desired behaviour hence the desired outcome (Hackett \& Betz, 1981). On the other hand, if an individual has a negative or low self-expectation then this behaviour also results in a set of behaviours which do not yield the desired outcomes on the job. This may also be referred to as low motivational level on part of the incumbent hence marring his career development. In the same paper, it was also highlighted that women tend to be at a higher rate of having low self-expectations hence not being able to achieve prominent positions in the hierarchy (Hackett \& Betz, 1981).

\subsection{Expectations from Leader}

The theories on leadership have beenchange and there is a significant inclusion of leader expectations and its linkage with the performance of the subordinates (Dansereau, Graen, \& Haga, 1975). There have been linkages between relationships and social communication or exchange which leads to higher level of work outcomes (Graen, Liden, \& Hoel, 1982; Graen, Novak, \& Sommerkamp, 1982). Social exchanges have been documented in a Vertical Dyad Linkage model (VDL) which highlights the social exchanges between leaders and members, this exchange creates an exceptional bond which results in a better outcome by the incumbent (Dansereau, Yammarino, \& Markham, 1995). This exchange helps transmit the expectation of the leader to the subordinate and cultivates a sense of increased selfefficacy hence resulting in increased performance on the job (Bhal \& Ansari, 2000; Dansereau et al., 1975; Graen \& Scandura, 1987; Liden \& Graen, 1980). On the other hand, high LMX members enjoy relationships that are characterized as being a partnership between a supervisor and subordinate and involve liking, loyalty, professional respect, and contributory behaviors (Dienesch \& Liden, 1986; Liden \& Maslyn, 1998).

\subsection{Pygmalion Leadership}

The concept of Pygmalion leadership refers to a leader who uses a set of behaviors that help the managers achieve high performance expectations. This definition has been developed after numerous empirical studies (Eden, 1990; Rosenthal, 1991; Rosenthal \& Rubin, 1978). Most of these studies have been conducted in military based situations (e.g., Eden \& Zuk, 1995). However, there is a study conducted by Sutton \& Woodman (1989) who have used sales associates as their population which did not support the Pygmalion model. Many research studies have discovered linkage between supervisor performance expectations and the subordinates' work performance, this outcomes maybe induced by the Pygmalion effect (McNatt, 2000).

\section{Research Methodology}

The research study is quantitative in nature and a self-reported questionnaire was developed using seven-point Likert scale. The questionnaire comprised of four variables and five questions each. These variables included Pygmalion leadership style, self-expectation, expectation from leaders and the performance of the subordinate.

\begin{tabular}{l|llll}
\hline 32 & July - December 2013 & Volume 11 & Number 2
\end{tabular}




\section{Data Analysis and Findings}

The sample population for the study was 230 respondents out of whom 118 were male and 112 were female. For further analysis of the data, the sample was divided into age and the level at which the individual is working namely Executive position, managerial position, middle management and Clerical position. The respondents' age varied between 20 to 50; whereas only 5 respondents were 50 plus in age. Around 115 respondents were at managerial position, 105 were at middle management positions and only 7 respondents were at clerical positions. The theory suggests that women workers have lower self-efficacy and hence it rompers their career development.

Table 1

Descriptive Analysis of Factors

\begin{tabular}{|lcccc|}
\hline & $\begin{array}{c}\text { Pygmalion Leadership } \\
\text { (Leader Behavior) }\end{array}$ & $\begin{array}{c}\text { Self- } \\
\text { Expectation }\end{array}$ & $\begin{array}{c}\text { Expectations } \\
\text { from Leader }\end{array}$ & $\begin{array}{c}\text { Performance } \\
\text { of the subordinate }\end{array}$ \\
\hline Mean & 4.69 & 4.85 & 4.82 & 4.92 \\
Standard Deviation & 1.35 & 1.17 & 1.11 & 1.14 \\
Kurtosis & 0.34 & 0.36 & 0.10 & 0.65 \\
Skewness & -0.65 & -0.60 & -0.47 & -0.78 \\
\hline
\end{tabular}

The mean of Pygmalion leadership style which is the behaviour being displayed by the leader results in the performance of the subordinate (4.9) with a median of 5, hence it can be inferred that the performance of subordinates is linked with the behaviour of the leader. Similarly, looking at the expectation of the leader (4.82) is the same as self-expectation (4.82). This is an interesting data as both expectations from the leader and self-expectation is same, this may be a direct link between the behaviour projected by the leader. The descriptive status does not provide any obvious link between the variables.

The correlation matrix reveals that the highest correlation is found in performance of the subordinate and the leader expectation i.e., 0.75 which is followed by self-expectations and leaders expectation 0.71 . Hence, this suggests that the theories related to expectations increasing performance or vice versa. Self-efficacy theory is also validated by the two variables expectations from the leader and the Pygmalion leadership style (0.68), this further validates the theory of Pygmalion leadership style and its impact on the performance of the subordinate. Analysis of variance is carried out to check whether all constructs are equal in terms of average response.

ANOVA
\begin{tabular}{|l|c|c|c|c|c|c|}
\hline Source of Variation & SS & df & MS & F & P-value & F crit \\
\cline { 2 - 7 } Between Groups & 6.80 & 3.00 & 2.27 & 1.58 & 0.19 & 2.61 \\
Within Groups & 1312.79 & 916.00 & 1.43 & & & \\
Total & 1319.59 & 919.00 & & & & \\
\hline
\end{tabular}

The above-mentioned ANOVA analysis indicates that there is no significant difference of the respondents' opinions among all constructs. This analysis signifies that the respondents opinion regarding the impact on performance is related to the leadership style, self-expectations

\begin{tabular}{lll|l}
\hline JISR-MSSE & Volume 11 & Number 2 & July - December 2013
\end{tabular}


and expectations of the leader. ANOVA test does not however highlight whether the difference of opinion if any exists.

\section{Demographic Analysis of Factors}

The following data was collected using the same leader and comparing the two variables of self-expectations and performance by the subordinate. It is assumed that the same leader has the same level of employee expectations and leadership behaviour.

To help understand the impact of leader behaviour and expectations on the performance of subordinates; an experiment was conducted whereby the leader was the same and the subordinates were both males and females. The following graph explains that same expectations and behaviour by the leader had different outcomes as far as the gender is concerned. The male subordinates had a mean of 4.58 on self expectations and the female subordinates had a mean of 4 , although the difference is not significant never the less there is a difference. This difference is further highlighted in the performance of the subordinate, the males had a mean of 6 and the females had a mean of 5 . This validates the theory presented by Hackett and Betz (1981).

Graph 1

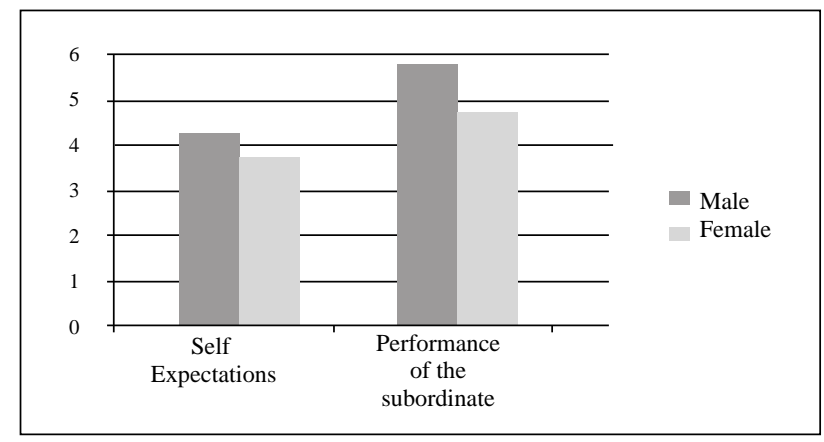

The following data is collected based on the age of the subordinates, it shows a general trend that the younger worker (20-25) have higher self expectations 6.5 and similar higher performance 6 . As the age progresses the expectations and performance are equalized. For this standy a sample of employees reporting to the same leader havebeen taken hence to measure the impact of age and their response to the leaders expectations and behaviour.

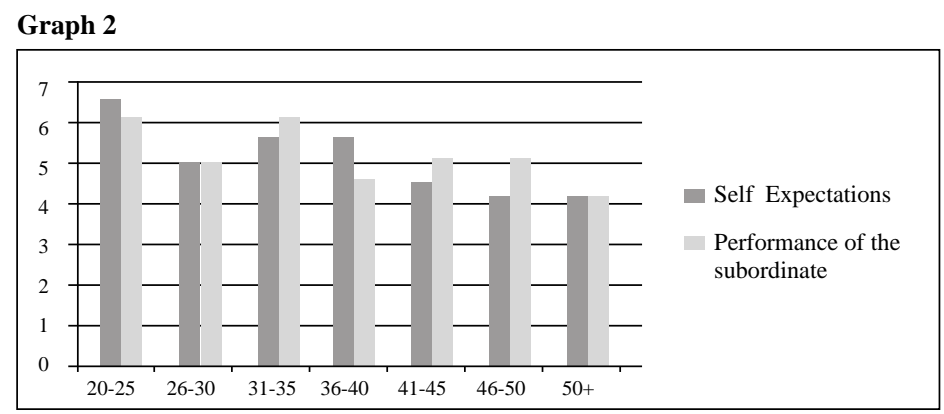




\section{Conclusion}

This study explored Pygamlion leadership style and performance of a subordinate, with selfexpectations and leader expectations. It can be concluded that there is a significant relationship between leadership style/behaviour and how an individual/subordinate would perform. Since the data was limited, it requires further research to explore the concept of Pygmalion in management. Earlier studies have all been conducted in military and educational settings; therefore, there is a dearth of secondary data related to the field of management. The current study yields that there is a link between expectations and performances. One way to incorporate the concept of Pygmalion leadership style into the work environment is to acknowledge performance accomplishments by verbal persuasion as well as verbal appreciation. Similarly, the research also found that there is a link between the level of performance and gender, to avoid these perceptions there is a need to avoid job discrimination, racism, prejudice and sexism. Further research is required to explore the reverse Pygmalion concept where the expectation of the subordinate can also impact the leadership style.

\section{References}

Aleassa, H. M. (2009). Investigating Consumers' Software Piracy Using An Extended Theory Of Reasoned Action. Doctor of Philosophy, Southern Illinois University Carbondale, Carbondale.

Avolio, Bruce J., \& Francis J. Yammarino. (2002). Transformational and Charismatic Leadership: The Road Ahead. New York: Erlbaum.

Bandura, A. (1977). Social Learning Theory. Englewood Cliffs, NJ: Prentice-Hall.

Betz, N. E., \& Hackett, G. (1997). Applications of Self-Efficacy Theory to the Career Assessment of Women. Journal of Career Assessment, 5(4), 383-402.

Bhal, K. T., \& Ansari, M. A. (2000). Measuring quality of interaction between leaders and members. Journal of Applied Social Psychology, 26, 945-972.

Conger, J.A. and R.N. Kanungo. (1998). Charismatic Leadership in Organizations. Thousands Oaks, CA: Sage Publications.

Dansereau F., Graen, G., G., \& Haga, W. J. (1975). A vertical dyad linkage approach to leadership within formal organizations: A longitudinal investigation of the role making process. Organizational Behavior and Human Performance, 13, 46-78.

Dansereau, F., Yammarino, F. J., \& Markham, S. E. (1995). Leadership: The multiple-level approaches. Leadership Quarterly, 6, 251-263.

Dienesch, R. M. S., \& Liden, R. C. (1986). Leader-member exchange model of leadership: A critique and further development. Academy of Management Review, 11, 618-634.

Eden, D. (1990). Consultant as Messiah: Applying expectation effects in managerial consultation. Consultation, 9, 37-50.

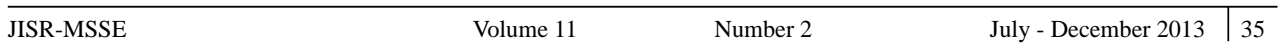


Eden, D. 1992. Leadership and expectations: Pygmalion effects and other self-fulfilling prophecies in organizations. Leadership Quarterly, 3, 271-305.

Eden, D., \& Zuk, Y. (1995). Seasickness as a self-fulfilling prophecy: Raising self-efficacy to boost performance at sea. Journal of Applied Psychology, 80, 628-635.

Graen, G. B., \& Liden, R. C., Hoel, W. (1982). Role of leadership in the employee withdrawal process. Journal of Applied Psychology, 67, 868-872.

Graen, G. B., \& Scandura, T. A. (1987). Toward a psychology of dyadic organizing. In L. L. Cummings \& B. M. Staw (Eds.), Research in Organizational Behavior (Volume 9, pp. 175-208). Greenwich, CT: JAI Press.

Graen, G. B., \&, Novak, M., \& Sommerkamp, O. (1982). The effects of leader-member exchange and job design on productivity and satisfaction: Testing a dual attachment model. Organizational Behavior and Human Performance, 30, 109-131.

Hackett, G., \& Betz, N. (1981). A self-efficacy approach to the career development of women. Journal of Vocational Behavior, 18 (3), 326-39.

Howell, J. P. \& Costley, D. L. (2001). Understanding Behaviors for Effective Leadership. Upper Saddle River, NJ: Prentice-Hall, Inc.

Judge, Timothy A., \& Ronald F. Piccolo. 2004. Transformational and Transactional Leadership: A meta analytic test of their relative validity. Journal of Applied Psychology, 89.

Kotter, J. P. (1996). Leading Change. Boston: Harvard Business School Press.

Kouzes, J. M. \& Posner, B. Z. (1995). The Leadership Challenge. San Francisco: JosseyBass.

Liden, R. C., \& Graen, G. (1980). Generalizability of the vertical dyad linkage model of leadership. Academy of Management Journal, 23, 451-465.

Liden, R. C., \& Maslyn, J. M. (1998). Multidimensionality of leader-member exchange: An empirical assessment through scale development. Journal of Management, 24, 43-73.

Likert, R. (1961). New Patterns of Management. New York: McGraw-Hill

Likert, R. (1967). The Human Organization: Its Management and Value. New York: McGraw Hill.

Livingston, J. S. (1969). Pygmalion in management. Harvard Business Review, 47(4), 8189.

Mc Gregor, D. (1960). The Human Side of Enterprise. New York: McGraw-Hill.

McNatt, D. B. (2000). Ancient Pygmalion joins contemporary management: A meta-analysis of the result. Journal of Applied Psychology, 85, 314-322.

\begin{tabular}{l|lll}
\hline 36 & July - December 2013 & Volume 11 & Number 2
\end{tabular}


Meier, Kenneth J., \& Laurence J. O’Toole, Jr. 2011. Isopraxis Leadership: Self-Efficacy, Managerial Strategy and Organizational Performance. Paper presented at the 11th Public Management Research Conference, Syracuse NY, June 2-4, 2011.

Rosenthal, R. (1991). Meta-Analytic Procedures for Social Science. Newbury Park, CA: Sage.

Rosenthal, R., \& Rubin, D. B. (1978). Interpersonal expectancy effects: The first 345 studies. Behavioral and Brain Sciences, 3, 377-386.

Shamir, B., Pillai, R., Bligh, M.C., \& Uhl-Bien, M. (Eds.) (2007). Follower-centered perspectives on leadership: A tribute to the memory of James R. Meindl. Retrieved from http://books.google.com/books.

Shahmir, Boas, Robert J. House, \& Michael B. Arthur. (1993). The Motivational Effects of Charismatic Leadership: A self-concept based theory. Organization Science.

Sutton, C.D., \& Woodman, R.W. (1989). Pygamlion goes to work: the effects of supervisor expectations in a retail settings. Journal of Applied Psychology, 74, 943-950.

Tanaka, J. S. (1987). How big is big enough?: Sample size and goodness of git in structural equation models with latent variables. Child Development, 58(1), 134-146.

Tull, D. S., \& Hawkins, D. I. (1987). Marketing research: measurement and method: Macmillan.

Wiersma, W. (1991). Research Methods in Education. Needham Heigghts: Ma: Allyn and Bacon.

Yukl, Gary. (2013). Leadership in Organizations, 8th ed. Essex: Pearson.

Zikmund, W. G. (2003). Business Research Methods. 7th ed. Oklahoma, EUA: Thomson. 


\section{Appendix}

\section{Questionnaire}

Instructions: Please circle one number per statement to indicate your view towards the statements below, where 1 means that you strongly disagree (or dislike) and 7 means that you strongly agree (or like).

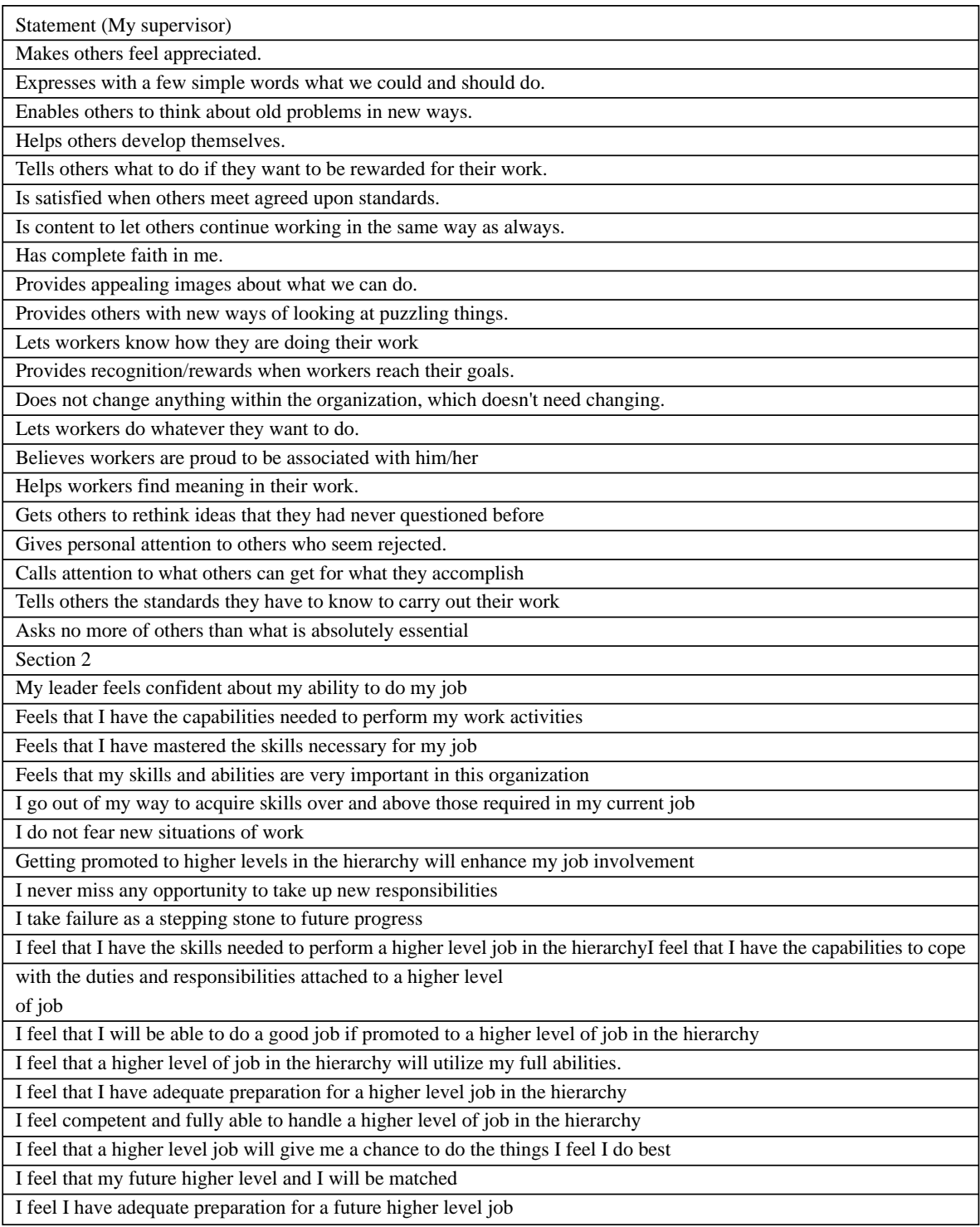

